\title{
Acid-base properties of functionalised tripodal polyamines and their interaction with nucleotides and nucleic acids
}

\author{
Alejandra Sornosa-Ten, ${ }^{a}$ M. Teresa Albelda, ${ }^{\text {a, }}$ Juan C. Frías, ${ }^{a}$ Enrique García-España, a, José M. \\ Llinares, ${ }^{\text {b Ana Budimir, }}$ and Ivo Piantanida.,
}

\author{
${ }_{5}$ Received (in $\left.X X X, X X X\right)$ Xth $X X X X X X X X X 200 X$, Accepted Xth XXXXXXXXX 200X \\ First published on the web Xth $X X X X X X X X X 200 X$ \\ DOI: 10.1039/b000000x
}

Novel, highly positively charged tripodal polyamines with appended heterocyclic moieties revealed an intriguing panel of protonation species within the biologically relevant range. Studied compounds bind nucleotide monophosphates by mostly 10 electrostatic interactions but only the imidazole analogue showed selectivity toward UMP in respect to other nucleotides. Strong binding of all the studied compounds to both ds-DNA and ds-RNA is to some extent selective toward the latter, showing rather rare RNA over DNA preference.

\section{Introduction}

Current challenges in diagnostics and emerging therapies for 15 treating genetic diseases call for novel, improved technologies for in vitro and in vivo targeting of nucleic acids. The rational design of new molecules able to interact selectively with nucleic acids has an immense practical application in several fields ranging from construction of nanomaterials to drug ${ }_{20}$ design and delivery. ${ }^{1}$ Over the past few decades, small molecules that bind to DNA have shown significant promise as diagnostic probes, reactive agents and therapeutics. Much attention has focused on the design of organic DNA-binding agents as well as on the improvement of DNA detection 25 methods in real time with high sensitivity. ${ }^{2,3}$ Despite the large number of cellular roles that RNA plays in biological processes, this macromolecule has been considered only recently an attractive target for therapeutic intervention. ${ }^{4}$ RNA is essential for replication, ${ }^{5}$ transcription ${ }^{6}$ and regulation 30 processes $^{7}$ protein function $^{8}$ and catalysis. ${ }^{9}$ The development of molecules that bind specifically to RNA opens exciting new ways in therapeutic strategies. . $^{4} 10$

It is well-known that the natural polyamines spermidine and spermine and their diamine precursor putrescine are 35 ubiquitous small basic molecules found in all eukaryotic cells which are implicated in many aspects of cellular physiology. ${ }^{11}$ Polyamines are essential for mammalian cell growth and development but their specific functions at the molecular level are still far from clear. Interactions of polyamines with 40 nucleic acids have been studied since the early $1960 \mathrm{~s}^{12}$ when it was found that they were bound to various cellular anions including DNA, RNA, proteins, and phospholipids. ${ }^{11,13}$ Some of us had previously reported on different studies dealing with the affinities of some tripodal polyamines $\left(\mathbf{L}^{\mathbf{1}}-\mathbf{L}^{\mathbf{3}}\right.$ in Scheme 45 1) towards RNA and DNA models. ${ }^{14}$ The high positive charge density coupled with high ligand flexibility allowed particularly deep and undistorted groove binding. Tripodal polyamines $\mathbf{L}^{\mathbf{1}}-\mathbf{L}^{\mathbf{3}}$ showed RNA groove preference. Also, the unfolding effects of $\mathrm{Cu}^{2+}$ in those ligands held promise for the 50 potential use of such complexes for RNA cleavage. In order to obtain tripodal ligands in which the functionalities at the terminal positions of the three arms could participate in the coordination of metal ions, we have prepared new receptors by attaching pyridine and imidazole units to the primary 55 nitrogens of the enlarged tripodal polyamine $\mathbf{L}^{\mathbf{1}}$. Here we report on the interaction with nucleotide monophosphates and nucleic acids of the tripodal polyamines $\mathbf{L}^{4}-\mathbf{L}^{7}$.

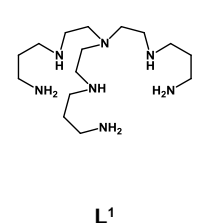

$\mathbf{L}^{1}$



$\mathbf{L}^{2}$

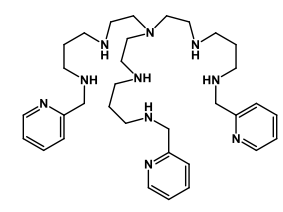

$\mathbf{L}^{4}$

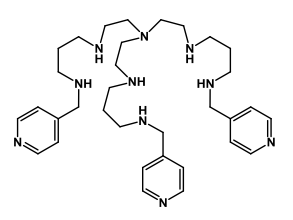

$\mathbf{L}^{6}$



$\mathbf{L}^{3}$

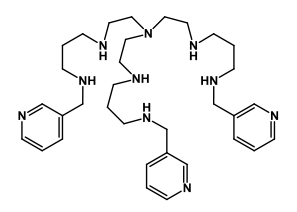

$\mathbf{L}^{5}$

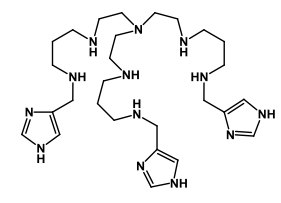

$\mathbf{L}^{7}$
Scheme 1 Structures of previously studied compounds $\left(\mathbf{L}^{\mathbf{1}}-\mathbf{L}^{3}\right)^{14}$ and of 60

$$
\text { derivatives }\left(\mathbf{L}^{4}-\mathbf{L}^{7}\right) \text { here analysed }
$$

\section{Results and discussion}

\section{Acid-base behaviour}

Table 1 collects the stepwise basicity constants for the tripodal ligands $\mathbf{L}^{4}-\mathbf{L}^{7}$ determined in $\mathrm{NaCl}$ or $\mathrm{NaClO}_{4} 0.15$ ${ }_{65} \mathrm{~mol} \cdot \mathrm{dm}^{-3}$ at $298.0 \pm 0.1 \mathrm{~K}$ as well as those for $\mathbf{L}^{1}-\mathbf{L}^{3}$ previously reported and determined at $298.1 \mathrm{~K}$ using 0.15 $\mathrm{mol} \cdot \mathrm{dm}^{-3} \mathrm{NaCl}$ as ionic strength. ${ }^{15}$ Figure 1 gives an example 
Table 1 Logarithms of the protonation constants of tripodal ligands $\mathbf{L}^{4}-\mathbf{L}^{7}$ determined in $\mathrm{NaCl}$ and $\mathbf{L}^{5}-\mathbf{L}^{6}$ determined in $\mathrm{NaClO}_{4} 0.15 \mathrm{~mol} \cdot \mathrm{dm}{ }^{-3}$ at $298.0 \pm$ $0.1 \mathrm{~K}$. For comparison, this table includes logarithms of the protonation constants of tripodal ligands $\mathbf{L}^{1}-\mathbf{L}^{3}$ determined in $\mathrm{NaCl} 0.15 \mathrm{~mol} \cdot \mathrm{dm}^{-3}$ at $298.0 \pm$ $0.1 \mathrm{~K}$.

\begin{tabular}{cccccccc} 
Reaction & $\mathbf{L}^{\mathbf{4}}$ & $\mathbf{L}^{\mathbf{5}}$ & $\mathbf{L}^{\mathbf{6}}$ & $\mathbf{L}^{\mathbf{7}}$ & $\mathbf{L}^{\mathbf{1} \mathbf{d}}$ & $\mathbf{L}^{\mathbf{2} \mathbf{d}}$ & $\mathbf{L}^{\mathbf{3} \mathbf{d}}$ \\
\hline $\mathrm{L}+\mathrm{H} \leftrightarrows \mathrm{HL}^{\mathrm{a}}$ & $10.41(2)^{\mathrm{b}}$ & $10.02(9)$ & $9.79(3)$ & $9.78(2)$ & $10.34(7)$ & $10.41(3)$ & $9.08(6)$ \\
$\mathrm{HL}+\mathrm{H} \leftrightarrows \mathrm{H}_{2} \mathrm{~L}$ & $9.46(1)$ & $9.19(6)$ & $9.43(3)$ & $9.53(1)$ & $10.26(2)$ & $9.87(2)$ & $8.70(5)$ \\
$\mathrm{H}_{2} \mathrm{~L}+\mathrm{H} \leftrightarrows \mathrm{H}_{3} \mathrm{~L}$ & $8.69(1)$ & $8.44(6)$ & $8.43(5)$ & $8.64(1)$ & $9.52(4)$ & $9.17(3)$ & $8.48(5)$ \\
$\mathrm{H}_{3} \mathrm{~L}+\mathrm{H} \leftrightarrows \mathrm{H}_{4} \mathrm{~L}$ & $7.61(1)$ & $7.48(6)$ & $7.65(6)$ & $7.83(1)$ & $8.68(4)$ & $8.02(3)$ & $7.76(4)$ \\
$\mathrm{H}_{4} \mathrm{~L}+\mathrm{H} \leftrightarrows \mathrm{H}_{5} \mathrm{~L}$ & $7.09(1)$ & $6.89(6)$ & $6.81(7)$ & $7.35(1)$ & $7.91(5)$ & $7.20(3)$ & $7.09(5)$ \\
$\mathrm{H}_{5} \mathrm{~L}+\mathrm{H} \leftrightarrows \mathrm{H}_{6} \mathrm{~L}$ & $6.35(1)$ & $6.41(6)$ & $6.76(7)$ & $6.72(1)$ & $7.37(4)$ & $5.78(8)$ & $6.80(4)$ \\
$\mathrm{H}_{6} \mathrm{~L}+\mathrm{H} \leftrightarrows \mathrm{H}_{7} \mathrm{~L}$ & - & $4.02(9)$ & $5.24(1)$ & $4.36(1)$ & $2.21(1)$ & $<2.00$ & $2.25(9)$ \\
$\mathrm{H}_{7} \mathrm{~L}+\mathrm{H} \leftrightarrows \mathrm{H}_{8} \mathrm{~L}$ & - & $3.11(9)$ & $4.08(1)$ & $4.17(1)$ & - & - & - \\
$\mathrm{H}_{8} \mathrm{~L}+\mathrm{H} \leftrightarrows \mathrm{H}_{9} \mathrm{~L}$ & - & $3.00(2)$ & $3.48(1)$ & $2.78(6)$ & - & - & - \\
$\log \beta^{\mathrm{e}}$ & 49.63 & 58.60 & 63.90 & 60.72 & 56.28 & 52.45 & 50.16
\end{tabular}

${ }^{a}$ Charges omitted. ${ }^{\mathrm{b}}$ Numbers in parentheses are standard deviations in the last significant figure. ${ }^{\mathrm{c}}$ Taken from reference $16 .{ }^{\mathrm{d}}$ Taken from reference 15. $5^{\mathrm{e}} \log \beta=\Sigma \log \mathrm{K}_{\mathrm{Hj} \mathrm{L}}$.

of distribution diagram for the species existing in equilibrium for the protonation of receptor $\mathbf{L}^{\mathbf{5}}$. Figure S1 (ESI $\left.{ }^{\dagger}\right)$ includes the distribution diagram for the species existing in equilibrium for all receptors $\mathbf{L}^{4}-\mathbf{L}^{7}$. The trend of the protonation constants 10 can be largely interpreted in terms of minimization of coulombic repulsion between same sign charges. ${ }^{17}$ All ligands $\mathbf{L}^{4}-\mathbf{L}^{7}$ present six relatively high basicity constants in agreement with the protonation of the secondary amine nitrogen atoms. (Table 1 and Figure S1, $\mathrm{ESI}^{\dagger}$ ).

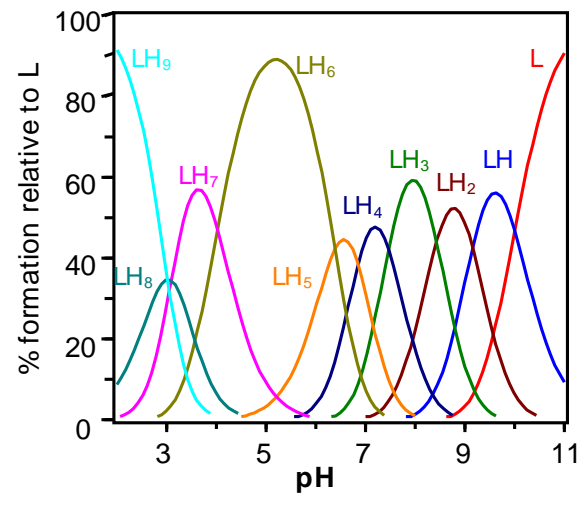

Figure 1 Distribution diagram for the species existing in equilibrium for the protonation of receptor $\mathbf{L}^{5}$

It is well established that electrostatic repulsion between positive charges separated by propylenic chains is 20 considerably lower than when the separation is by ethylenic chains. ${ }^{18}$ This is the reason for the relatively small decrease in basicity observed in every one of the six first protonations of all three ligands. These stepwise protonation constants are in all cases lower than those reported for precursor $\mathbf{L}^{\mathbf{1}}$, which 25 can be attributed to the electron withdrawing character of the pyridine and imidazole rings ${ }^{17,18,19}$ The next three basicity constants of $\mathbf{L}^{5}-\mathbf{L}^{\mathbf{7}}$ can be ascribed to the protonation steps of the pyridine and imidazole rings attached to the arms. Acidbase behavior of ligand $\mathbf{L}^{4}$ has been previously reported. ${ }^{20}$ The
30 most important difference between them resides on the higher basicity of the pyridine nitrogens of $\mathbf{L}^{\mathbf{5}}-\mathbf{L}^{\mathbf{6}}$. The nitrogens of the imidazole moieties in $\mathbf{L}^{7}$ have a basicity between the 3 and ${ }^{4}$-substituted pyridines in $\mathbf{L}^{\mathbf{5}}$ and $\mathbf{L}^{6}$. For $\mathbf{L}^{\mathbf{4}}$ the values determined spectroscopically for the last three protonation 35 steps are below 2 logarithmic units. In all ligands the apical nitrogen atom would not bear any neat protonation.

\section{Interaction with Nucleotides}

Detection of nucleosides and nucleotides in aqueous medium is of paramount importance as they form the fundamental 40 units of all the life forms. However, differentiation among naturally occurring nucleobases based on different hydrogen bonding patterns within the artificial receptor is strongly limited due to competitive hydrogen bonding of water. ${ }^{21}$ Therefore, although many artificial receptors have been 45 reported, most of them lack of base selectivity. As a matter of fact, until now there are only a few receptors able to selectively bind specific nucleobases in water. Lhomme et al. showed the capacity of aryl-nucleobase conjugates to recognize certain nucleobases in water, ${ }^{22}$ while Kimura et al. 50 demonstrated that zinc(II) complexes of the macrocyclic tetraamine 1,4,7,10-tetraazacyclododecane (cyclen) have a unique propensity to bind with deprotonated imides like thymine and, uracil, by forming non-covalent stable complexes in biologically relevant conditions. ${ }^{23}$ Moreover, 55 cyclen units appended with aromatic rings such as acridine and ditopic receptors yielded binding constants for TMP and UMP up to $\mathrm{K}=10^{7} \mathrm{M}^{-1}$. ${ }^{24}$ In order to explore the possibility to use metal complexes for simultaneous detection of nucleotides and to better understand how the interaction with 60 the nucleic acids occurs, an analysis of the interaction of the receptors $\mathbf{L}^{4}$ and $\mathbf{L}^{7}$ with nucleotide monophosphates (AMP, CMP, GMP, TMP and UMP) was carried out. The electrostatic interactions between the positively charged receptors and the negatively charged mononucleotides are 65 expected to lead to the formation of complexes. 
Table 2 Logarithms of the stability constants for the interaction of monophosphate nucleotides $\left(\mathrm{MP}^{2-} \equiv\right.$ A) with tripodal polyamine $\mathbf{L}^{4}$ determined at 298.0 $\pm 0.1 \mathrm{~K}$ in $0.15 \mathrm{~mol} \cdot \mathrm{dm}^{-3} \mathrm{NaCl}$.

\begin{tabular}{|c|c|c|c|c|c|c|}
\hline Reaction & AMP & CMP & Reaction & GMP & TMP & UMP \\
\hline $\mathrm{A}+\mathrm{HL} \leftrightarrows \mathrm{HAL}$ & $3.56(3)$ & $2.96(1)$ & $\mathrm{H}_{-1} \mathrm{~A}+\mathrm{HL} \leftrightarrows \mathrm{AL}$ & - & $3.88(1)$ & $3.59(1)$ \\
\hline $\mathrm{A}+\mathrm{H}_{2} \mathrm{~L} \leftrightarrows \mathrm{H}_{2} \mathrm{AL}$ & $3.86(3)$ & $3.06(1)$ & $\mathrm{H}_{-1} \mathrm{~A}+\mathrm{H}_{2} \mathrm{~L} \leftrightarrows \mathrm{HAL}$ & $4.66(2)$ & $4.11(1)$ & $3.77(1)$ \\
\hline $\mathrm{A}+\mathrm{H}_{3} \mathrm{~L} \leftrightarrows \mathrm{H}_{3} \mathrm{AL}$ & $4.10(4)$ & $3.13(1)$ & $\mathrm{H}_{-1} \mathrm{~A}+\mathrm{H}_{3} \mathrm{~L} \leftrightarrows \mathrm{H}_{2} \mathrm{AL}$ & - & - & - \\
\hline $\mathrm{A}+\mathrm{H}_{4} \mathrm{~L} \leftrightarrows \mathrm{H}_{4} \mathrm{AL}$ & $4.35(3)$ & $3.25(1)$ & $\mathrm{H}_{-1} \mathrm{~A}+\mathrm{H}_{4} \mathrm{~L} \leftrightarrows \mathrm{H}_{3} \mathrm{AL}$ & - & - & - \\
\hline $\mathrm{A}+\mathrm{H}_{5} \mathrm{~L} \leftrightarrows \mathrm{H}_{5} \mathrm{AL}$ & $4.33(4)$ & $3.14(1)$ & $\mathrm{H}_{-1} \mathrm{~A}+\mathrm{H}_{5} \mathrm{~L} \leftrightarrows \mathrm{H}_{4} \mathrm{AL}$ & - & - & - \\
\hline $\mathrm{A}+\mathrm{H}_{6} \mathrm{~L} \leftrightarrows \mathrm{H}_{6} \mathrm{AL}$ & $4.71(3)$ & $3.47(1)$ & $\mathrm{H}_{-1} \mathrm{~A}+\mathrm{H}_{6} \mathrm{~L} \leftrightarrows \mathrm{H}_{5} \mathrm{AL}$ & - & - & - \\
\hline $\mathrm{HA}+\mathrm{HL} \leftrightarrows \mathrm{H}_{2} \mathrm{AL}$ & - & & $\mathrm{A}+\mathrm{HL} \leftrightarrows \mathrm{HAL}$ & $4.47(2)$ & $3.78(1)$ & $3.35(1)$ \\
\hline $\mathrm{HA}+\mathrm{H}_{2} \mathrm{~L} \leftrightarrows \mathrm{H}_{3} \mathrm{AL}$ & - & - & $\mathrm{A}+\mathrm{H}_{2} \mathrm{~L} \leftrightarrows \mathrm{H}_{2} \mathrm{AL}$ & $4.08(3)$ & $3.45(1)$ & $3.12(2)$ \\
\hline $\mathrm{HA}+\mathrm{H}_{3} \mathrm{~L} \leftrightarrows \mathrm{H}_{4} \mathrm{AL}$ & - & - & $\mathrm{A}+\mathrm{H}_{3} \mathrm{~L} \leftrightarrows \mathrm{H}_{3} \mathrm{AL}$ & $4.50(2)$ & $3.36(1)$ & $3.01(2)$ \\
\hline $\mathrm{HA}+\mathrm{H}_{4} \mathrm{~L} \leftrightarrows \mathrm{H}_{5} \mathrm{AL}$ & - & - & $\mathrm{A}+\mathrm{H}_{4} \mathrm{~L} \leftrightarrows \mathrm{H}_{4} \mathrm{AL}$ & $4.68(2)$ & $3.51(1)$ & $3.30(2)$ \\
\hline $\mathrm{HA}+\mathrm{H}_{5} \mathrm{~L} \leftrightarrows \mathrm{H}_{6} \mathrm{AL}$ & $4.99(3)$ & $3.83(1)$ & $\mathrm{A}+\mathrm{H}_{5} \mathrm{~L} \leftrightarrows \mathrm{H}_{5} \mathrm{AL}$ & $4.84(2)$ & $3.40(1)$ & $3.20(1)$ \\
\hline \multirow[t]{4}{*}{$\mathrm{HA}+\mathrm{H}_{6} \mathrm{~L} \leftrightarrows \mathrm{H}_{7} \mathrm{AL}$} & $3.97(4)$ & - & $\mathrm{A}+\mathrm{H}_{6} \mathrm{~L} \leftrightarrows \mathrm{H}_{6} \mathrm{AL}$ & $5.22(2)$ & - & $3.60(1)$ \\
\hline & - & - & $\mathrm{A}+\mathrm{H}_{7} \mathrm{~L} \leftrightarrows \mathrm{H}_{7} \mathrm{AL}$ & - & - & - \\
\hline & - & - & $\mathrm{HA}+\mathrm{H}_{5} \mathrm{~L} \leftrightarrows \mathrm{H}_{6} \mathrm{AL}$ & - & $3.77(1)$ & $3.80(1)$ \\
\hline & - & - & $\mathrm{HA}+\mathrm{H}_{6} \mathrm{~L} \leftrightarrows \mathrm{H}_{7} \mathrm{AL}$ & $4.89(2)$ & - & - \\
\hline
\end{tabular}

${ }^{a}$ Charges omitted. ${ }^{\mathrm{b}}$ Numbers in parentheses are standard deviations in the last significant figure.

5 Table 3 Logarithms of the stability constants for the interaction of monophosphate nucleotides $\left(\mathbf{M P}{ }^{2-} \equiv\right.$ A) with tripodal polyamine $\mathbf{L}^{7}$ determined at 298.0 $\pm 0.1 \mathrm{~K}$ in $0.15 \mathrm{~mol} \cdot \mathrm{dm}^{-3} \mathrm{NaCl}$.

\begin{tabular}{|c|c|c|c|c|c|c|}
\hline Reaction & AMP & CMP & Reaction & GMP & TMP & UMP \\
\hline $\mathrm{A}+\mathrm{HL} \leftrightarrows \mathrm{HAL}$ & $3.22(1)$ & $2.44(1)$ & $\mathrm{H}_{-1} \mathrm{~A}+\mathrm{HL} \leftrightarrows \mathrm{AL}$ & $3.66(3)$ & $3.30(1)$ & $4.40(1)$ \\
\hline $\mathrm{A}+\mathrm{H}_{2} \mathrm{~L} \leftrightarrows \mathrm{H}_{2} \mathrm{AL}$ & $3.23(1)$ & $2.21(1)$ & $\mathrm{H}_{-1} \mathrm{~A}+\mathrm{H}_{2} \mathrm{~L} \leftrightarrows \mathrm{HAL}$ & $3.44(4)$ & $3.72(1)$ & $5.03(1)$ \\
\hline $\mathrm{A}+\mathrm{H}_{3} \mathrm{~L} \leftrightarrows \mathrm{H}_{3} \mathrm{AL}$ & $3.57(1)$ & $2.41(2)$ & $\mathrm{H}_{-1} \mathrm{~A}+\mathrm{H}_{3} \mathrm{~L} \leftrightarrows \mathrm{H}_{2} \mathrm{AL}$ & - & - & - \\
\hline $\mathrm{A}+\mathrm{H}_{4} \mathrm{~L} \leftrightarrows \mathrm{H}_{4} \mathrm{AL}$ & $3.80(1)$ & $2.80(1)$ & $\mathrm{H}_{-1} \mathrm{~A}+\mathrm{H}_{4} \mathrm{~L} \leftrightarrows \mathrm{H}_{3} \mathrm{AL}$ & - & - & - \\
\hline $\mathrm{A}+\mathrm{H}_{5} \mathrm{~L} \leftrightarrows \mathrm{H}_{5} \mathrm{AL}$ & $3.90(1)$ & $2.86(1)$ & $\mathrm{H}_{-1} \mathrm{~A}+\mathrm{H}_{5} \mathrm{~L} \leftrightarrows \mathrm{H}_{4} \mathrm{AL}$ & - & - & - \\
\hline $\mathrm{A}+\mathrm{H}_{6} \mathrm{~L} \leftrightarrows \mathrm{H}_{6} \mathrm{AL}$ & $4.40(1)$ & $3.52(1)$ & $\mathrm{H}_{-1} \mathrm{~A}+\mathrm{H}_{6} \mathrm{~L} \leftrightarrows \mathrm{H}_{5} \mathrm{AL}$ & - & - & - \\
\hline $\mathrm{HA}+\mathrm{L} \leftrightarrows \mathrm{HAL}$ & - & - & $\mathrm{A}+\mathrm{L} \leftrightarrows \mathrm{AL}$ & $3.80(3)$ & $2.98(1)$ & $4.81(1)$ \\
\hline $\mathrm{HA}+\mathrm{HL} \leftrightarrows \mathrm{H}_{2} \mathrm{AL}$ & - & - & $\mathrm{A}+\mathrm{HL} \leftrightarrows \mathrm{HAL}$ & $3.31(4)$ & $3.14(1)$ & $4.67(1)$ \\
\hline $\mathrm{HA}+\mathrm{H}_{2} \mathrm{~L} \leftrightarrows \mathrm{H}_{3} \mathrm{AL}$ & - & - & $\mathrm{A}+\mathrm{H}_{2} \mathrm{~L} \leftrightarrows \mathrm{H}_{2} \mathrm{AL}$ & $3.27(4)$ & $2.92(1)$ & $4.32(1)$ \\
\hline $\mathrm{HA}+\mathrm{H}_{3} \mathrm{~L} \leftrightarrows \mathrm{H}_{4} \mathrm{AL}$ & - & - & $\mathrm{A}+\mathrm{H}_{3} \mathrm{~L} \leftrightarrows \mathrm{H}_{3} \mathrm{AL}$ & $3.16(3)$ & $3.25(1)$ & $4.34(1)$ \\
\hline $\mathrm{HA}+\mathrm{H}_{4} \mathrm{~L} \leftrightarrows \mathrm{H}_{5} \mathrm{AL}$ & - & - & $\mathrm{A}+\mathrm{H}_{4} \mathrm{~L} \leftrightarrows \mathrm{H}_{4} \mathrm{AL}$ & $3.40(3)$ & $3.43(1)$ & $4.41(1)$ \\
\hline $\mathrm{HA}+\mathrm{H}_{5} \mathrm{~L} \leftrightarrows \mathrm{H}_{6} \mathrm{AL}$ & $4.61(1)$ & - & $\mathrm{A}+\mathrm{H}_{5} \mathrm{~L} \leftrightarrows \mathrm{H}_{5} \mathrm{AL}$ & $3.46(2)$ & $3.56(1)$ & $4.40(1)$ \\
\hline $\mathrm{HA}+\mathrm{H}_{6} \mathrm{~L} \leftrightarrows \mathrm{H}_{7} \mathrm{AL}$ & $3.72(1)$ & $1.87(3)$ & $\mathrm{A}+\mathrm{H}_{6} \mathrm{~L} \leftrightarrows \mathrm{H}_{6} \mathrm{AL}$ & $3.90(2)$ & $3.93(1)$ & $4.67(1)$ \\
\hline $\mathrm{HA}+\mathrm{H}_{7} \mathrm{~L} \leftrightarrows \mathrm{H}_{8} \mathrm{AL}$ & $3.55(1)$ & - & $\mathrm{A}+\mathrm{H}_{7} \mathrm{~L} \leftrightarrows \mathrm{H}_{7} \mathrm{AL}$ & - & - & \\
\hline \multirow[t]{3}{*}{$\mathrm{H}_{2} \mathrm{~A}+\mathrm{H}_{5} \mathrm{~L} \leftrightarrows \mathrm{H}_{7} \mathrm{AL}$} & $3.55(1)$ & - & $\mathrm{HA}+\mathrm{H}_{5} \mathrm{~L} \leftrightarrows \mathrm{H}_{6} \mathrm{AL}$ & - & $3.93(3)$ & $4.81(1)$ \\
\hline & & & $\mathrm{HA}+\mathrm{H}_{6} \mathrm{~L} \leftrightarrows \mathrm{H}_{7} \mathrm{AL}$ & $2.94(3)$ & $2.89(2)$ & $3.69(1)$ \\
\hline & & & $\mathrm{HA}+\mathrm{H}_{7} \mathrm{~L} \leftrightarrows \mathrm{H}_{8} \mathrm{AL}$ & & & $3.41(1)$ \\
\hline
\end{tabular}

${ }^{a}$ Charges omitted. ${ }^{\mathrm{b}}$ Numbers in parentheses are standard deviations in the last significant figure. 

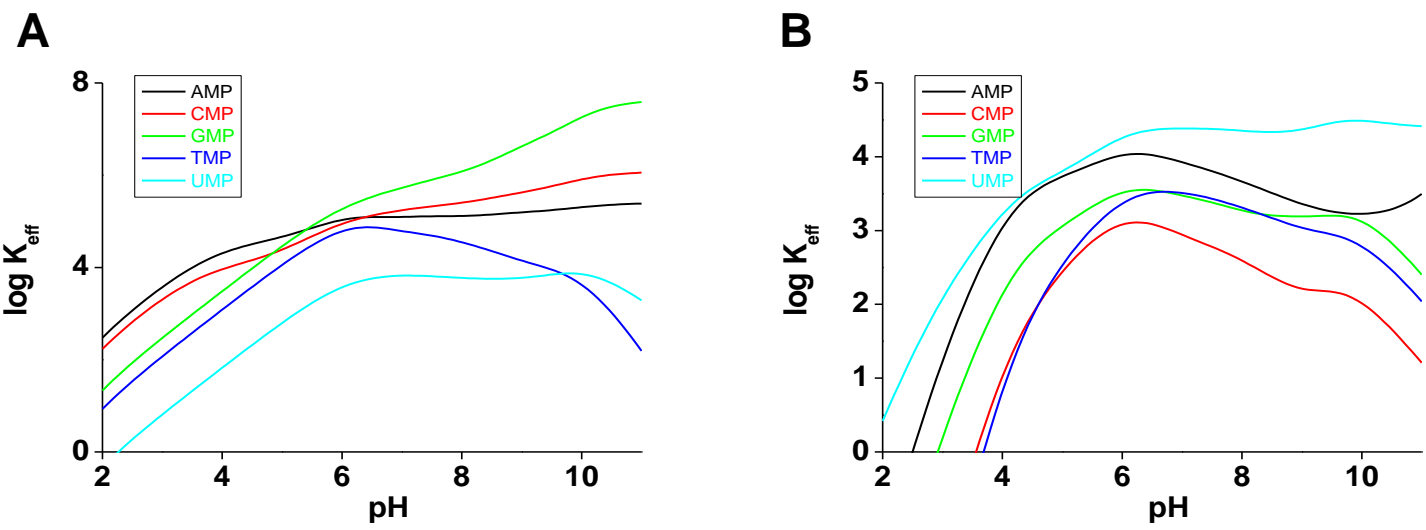

Figure 2 Plot of the effective conditional constants $v s$. $\mathrm{pH}$ for the interaction of tripodal polyamines A) $\mathbf{L}^{4}$ and B) $\mathbf{L}^{7}$ with monophosphate nucleotides AMP, CMP, GMP, TMP and UMP.

5 Tables 2 and 3 collect the corresponding data for the interaction of monophosphate nucleotides with the tripodal receptors $\mathbf{L}^{\mathbf{4}}$ and $\mathbf{L}^{7}$ respectively. Previously it was necessary to determine the protonation constants of the different nucleotides under the experimental conditions used in this 10 work. The results are collected in Table S1, (ESI $\dagger$ ). GMT, TMP and UMP show a deprotonation process of the imide nitrogen in the heterocyclic base. ${ }^{23}$ AMP and CMP bear a protonation of the nitrogen $\mathrm{N} 1$ in the aromatic ring.

By examining the different values of binding constants, it is 15 interesting to notice that all tripodal receptors are able to form mononuclear complexes of significant stability with the studied nucleotides. Figure S2 (ESI $\dagger$ ) includes distribution diagrams for the studied systems and shows that the adduct species clearly predominate in a wide $\mathrm{pH}$ range. Ligand $\mathbf{L}^{4}$ 20 forms species with stoichiometries $\mathrm{H}_{\mathrm{x}} \mathrm{LA}$ where $\mathrm{x}$ varies from 1 to 7 and receptor $\mathbf{L}^{7}$ gives species with a higher protonation degree where $\mathrm{x}$ varies from 0 to 8 . Formation of these protonated species can be explained by means of the basicity of the ligands. The ligand with imidazole groups is more 25 basic, so the protonation of the aromatic nitrogen is produced at a higher $\mathrm{pH}$. Ligand $\mathbf{L}^{4}$ has their nitrogen atoms in pyridine moieties protonated at more acidic $\mathrm{pH}$. To analyze the A:L adduct-formation constants for the different systems shown in Table 2, care must be exerted in comparing the right equilibria 30 and values of stability constants. Since both the substrate and the receptors participate in overlapping proton-transfer processes, translating the cumulative stability constants into representative stepwise constants is not always straightforward. To do so, one has to consider the basicities of 35 the nucleotides and of the different ligands and assume that the interaction will not affect much the $\mathrm{pH}$ range of existence of the protonated species of nucleotides and L. If this is taken into account, stepwise constants can be deduced. However, the most unambiguous way to compare the relative stabilities 40 of the different systems and to establish selectivity ratios is to use effective constants. The effective constants $\mathrm{K}_{\text {eff }}$ are calculated at each $\mathrm{pH}$ value as the quotient between the overall amount of complexed species and the overall amounts of free receptor and substrate independently of their 45 protonation degree.

$$
K_{e f f}=\frac{\sum\left[H_{i+j} A L\right]}{\sum\left[H_{i} A\right] \sum\left[H_{j} L\right]}
$$

Figure 2 represents the plot of the logarithms of the effective conditional constant $v s$. $\mathrm{pH}$ for the interaction of tripodal polyamine $\mathbf{L}^{4}$ and $\mathbf{L}^{7}$ with nucleotide monophosphates AMP, ${ }_{50}$ CMP, GMP, TMP and UMP.

The present results demonstrate the ability of these tripodal polyamine receptors to strongly bind nucleotides, giving a variety of complex species. ${ }^{1} \mathrm{H}-\mathrm{NMR}$ and ${ }^{31} \mathrm{P}-\mathrm{NMR}$ experiments were done in order to confirm the existence of 55 the complexes. All spectra show only small variations of the signals (Figures S3 and S4, ESI ${ }^{\dagger}$ ).

\section{Interaction with Nucleic Acids}

\section{Physico- chemical properties of aqueous solutions}

In order to decide which was the most appropiate $\mathrm{pH}$ to carry ${ }_{60}$ out the experiments we took into account the previously discussed acid-base properties of the compounds. It was obvious that within the biologically relevant $\mathrm{pH}$ range $(\mathrm{pH}=$ $5-8$ ), only at $\mathrm{pH}=5$ most of the studied compounds are present in one dominant protonation form, except $\mathbf{L}^{6}$, see ${ }_{65}$ Figures 1 and $\mathrm{S} 1\left(\mathrm{ESI}^{\dagger}\right)$ for a plot of the distribution diagrams. The number of positive charges that each one of the ligands bears at the $\mathrm{pH}$ of study is as follows: $\mathbf{L}^{4}(6+), \mathbf{L}^{\mathbf{5}}(6+), \mathbf{L}^{6}(6-$ $7+)$ and $\mathbf{L}^{7}(6-7+)$.

Therefore, all further experiments were done at $\mathrm{pH}=5.0$, in 70 citrate buffer, $I=0.05 \mathrm{~mol} \mathrm{dm}^{-3}$. All the stock solutions of the compounds were prepared in re-distilled water and kept in dark and cold place $\left(+8{ }^{\circ} \mathrm{C}\right)$. While in in these conditions the solutions were stable for about 2-3 weeks (checked by UV/vis spectroscopy), at room temperature they were stable only for 75 several days. Changes of the UV/Vis spectra of compounds upon the temperature increase up to $98{ }^{\circ} \mathrm{C}$ were negligible and reproducibility of UV/Vis spectra upon cooling back to $25{ }^{\circ} \mathrm{C}$ was excellent. 
Study of the interactions of $\boldsymbol{L}^{4}-\boldsymbol{L}^{7}$ with $d s-D N A$ and $d s-R N A$ in aqueous media

The UV/vis titration experiments were hampered by instant precipitation upon addition of the ct-DNA to solutions of any 5 of the studied compounds $\left(\mathrm{c} \approx 10^{-5} \mathrm{~mol} \mathrm{\textrm {dm } ^ { - 3 }}\right)$. As an alternative method for estimation of affinity, at least as a comparison of ability of studied molecules to compete for binding with classical intercalators already bound to dspolynucleotides, ${ }^{25}$ we have performed ethidium bromide (EB) 10 displacement assays (Figure S5, $\mathrm{ESI}^{\dagger}$ ).

The obtained $\mathrm{IC}_{50}=1.2-0.15$ suggest that affinities of $\mathbf{L}^{4}-\mathbf{L}^{7}$ toward ct-DNA and poly A-poly $U$ are comparable to the affinity of EB. Since the structures of $\mathbf{L}^{4}-\mathbf{L}^{7}$ do not support intercalation into ds-DNA/RNA as a binding mode but more 15 likely an electrostatic interactions, the obtained IC $_{50}$ values cannot be used for accurate calculation of binding constants but only as a measure of high affinity $(\log K s>5)$.

Table 4 The ${ }^{a} \Delta T_{m}$ values $\left({ }^{\circ} \mathrm{C}\right)$ of ct-DNA upon addition of different ratios ${ }^{\mathrm{b}} \boldsymbol{r}$ of $\mathbf{L}^{4}-\mathbf{L}^{7}$ at $\mathrm{pH}=5.0$ (citrate buffer $I=0.05 \mathrm{~mol} \cdot \mathrm{dm}^{-3}$ )

\begin{tabular}{c|c|c|c|c}
\hline \multirow{2}{*}{${ }^{\mathrm{b}} \boldsymbol{r}=$} & \multicolumn{5}{|c}{ ct-DNA } \\
\cline { 3 - 6 } & 0.1 & 0.2 & 0.3 & 0.5 \\
\hline $\mathbf{L}^{\mathbf{4}}$ & 5.95 & 7.55 & 10.15 & 10.7 \\
$\mathbf{L}^{5}$ & 5.30 & 10.35 & 12.30 & 11.85 \\
$\mathbf{L}^{\mathbf{6}}$ & 4.55 & 6.10 & 12.30 & 12.65 \\
$\mathbf{L}^{7}$ & 3.0 & 7.4 & 11.0 & 20.0 \\
\hline
\end{tabular}

${ }_{20}{ }^{a}$ Error in $\Delta T_{m}: \pm 0.5^{\circ} \mathrm{C} ;{ }^{\mathrm{b}} \boldsymbol{r}=$ [compound] $/[\mathrm{ct}-\mathrm{DNA}]$.

It is well known that upon heating, ds-helices of polynucleotides at well-defined temperature $\left(T_{m}\right.$ value) dissociate into two single stranded polynucleotides. Noncovalent binding of small molecules to ds-polynucleotides 25 usually has certain effect on the thermal stability of helices thus giving different $T_{m}$ values. Difference between $T_{m}$ value of free polynucleotide and complex with a small molecule $\left(\Delta T_{m}\right.$ value) is an important factor in the characterisation of small molecule/ds-polynucleotide interactions Addition of any

30 of the studied compounds strongly stabilised the double helix of ct-DNA (Table 4). The pronounced nonlinear dependence of $\Delta T_{m}$ values on the ratio $\boldsymbol{r}_{\text {[compound]/[ct-DNA] }}$ obtained for $\mathbf{L}^{4}-\mathbf{L}^{\mathbf{6}}$ suggested saturation of binding sites at about $\boldsymbol{r}=0.3$. Intriguingly, no saturation of binding sites was observed for
${ }_{35} \mathbf{L}^{7}$ even up to $\boldsymbol{r}_{\text {[compound }] /[\text { ct-DNA] }}=0.5$. Impact of the ionic strength of aqueous solution on the binding of small molecules to DNA/RNA depends heavily on a type of non-covalent interactions. Namely, under experimental conditions similar to those applied in this work, 40 increase of ionic strength for one order of magnitude resulted in diminished (but still measurable) stabilization effect of classical intercalator ethidium bromide on ct-DNA. ${ }^{26}$ At variance to that, comparable increase of ionic strength (addition of $0.1 \mathrm{~mol} \cdot \mathrm{dm}^{-3} \mathrm{NaCl}$ to conditions presented in ${ }_{45}$ Table 1) completely abolished the stabilisation effect of $\mathbf{L}^{4}$ on ct-DNA, pointing toward dominant role of electrostatic interactions in binding of $\mathbf{L}^{4}-\mathbf{L}^{7}$ to polynucleotides.

Thermal denaturation of poly A-poly $\mathrm{U}$ at $\mathrm{pH}=5.0$ yielded biphasic transition. The first transition at about $T_{m}=30 \pm 1{ }^{\circ} \mathrm{C}$ 50 is attributed to denaturation of poly A-poly $\mathrm{U}$ and the second transition at about $T_{m}=79 \pm 1{ }^{\circ} \mathrm{C}$ is attributed to denaturation of poly $\mathrm{AH}^{+}$- poly $\mathrm{AH}^{+}$, since poly $\mathrm{A}$ at $\mathrm{pH}=5.0$ is mostly protonated and forms ds-polynucleotide (poly $\mathrm{AH}^{+}$- poly $\left.\mathrm{AH}^{+}\right){ }^{27,28}$ For comparison, thermal denaturation of only poly ${ }_{55} \mathrm{AH}^{+}$- poly $\mathrm{AH}^{+}$as well as of the DNA analogue (poly dA poly dT) were performed.

Preliminary experiments with poly A - poly U revealed much stronger stabilisation effects caused by addition of all studied compounds than observed in ct-DNA experiments. In 60 addition, at ratio $\boldsymbol{r}_{\text {[compound]/[polynucleotide] }}>0.2$ for most of compounds precipitation was observed, thus hampering the measurements. Therefore, more detailed experiments with poly $\mathrm{A}$ - poly $\mathrm{U}$, poly dA - poly dT and poly $\mathrm{AH}^{+}$- poly $\mathrm{AH}^{+}$ were done at ratios $r<0.1$ (Table 5).

${ }_{65}$ Even at ratio $r_{\text {[compound]/[polynucleotide] }}=0.01$, addition of all studied compounds caused measurable stabilisation of poly A - poly $\mathrm{U}$ by $\Delta T_{m}$ values roughly comparable to those obtained for ds-DNA's at 10 times higher ratios (Tables 4 and 5).

Further increases of the $\mathbf{L}^{4}-\mathbf{L}^{7}$ concentration $70\left(\mathrm{r}_{\text {[compound] }] /[\text { polynucleotide }]}=0.05-0.1\right)$ stabilised even more poly A-poly $U$, shifting the melting transitions in the range between $70-90{ }^{\circ} \mathrm{C}$. Consequently the denaturation curve of poly A-poly $\mathrm{U}$ overlapped with the thermal transition of poly $\mathrm{AH}^{+}$-poly $\mathrm{AH}^{+} .^{27,28}$ Comparison of thermal denaturation 75 curves for the same ratio $\boldsymbol{r}$ obtained for poly A-poly $U$ and $\mathrm{AH}^{+}$-poly $\mathrm{AH}^{+}$(Table 5, Figures 4 and 5), respectively, allowed in the most cases for an accurate assignation of thermal transitions to corresponding polynucleotides. 
Table 5 The ${ }^{\mathrm{a}} \Delta T_{m}$ values $\left({ }^{\circ} \mathrm{C}\right)$ of poly A - poly $\mathrm{U}$, poly $\mathrm{AH}^{+}$-poly $\mathrm{AH}^{+}$and poly dA-poly dT upon addition of different ratios ${ }^{\mathrm{b}} \boldsymbol{r}$ of $\mathbf{L}^{4}-\mathbf{L}^{7}$ at $\mathrm{pH}=5.0$ (citrate buffer $I=0.05 \mathrm{~mol} \cdot \mathrm{dm}^{-3}$ ).

\begin{tabular}{cccccc}
\hline & ${ }^{\mathrm{b}} \mathbf{r}=$ & $\mathbf{L}^{\mathbf{4}}$ & $\mathbf{L}^{\mathbf{5}}$ & $\mathbf{L}^{\mathbf{6}}$ & $\mathbf{L}^{\mathbf{7}}$ \\
\hline & 0.01 & ${ }^{\mathrm{c}}+2.9 /-0.5$ & ${ }^{\mathrm{c}}+3.4 /-0.6$ & ${ }^{\mathrm{c}}+2.2 /-1.0$ & ${ }^{\mathrm{c}}+0.5 /-0.6$ \\
poly A-polyU & 0.05 & ${ }^{\mathrm{c}}+42.1 /-4.2$ & ${ }^{\mathrm{c}}+46.5 / 0$ & ${ }^{\mathrm{c}}+51.4 /-2.8$ & $\begin{array}{c}{ }^{\mathrm{c}}+3.5 \text { and } \\
+51.6 / 0\end{array}$ \\
& 0.1 & $+51.1 /-11.4$ & ${ }^{\mathrm{c}}+46.1 / 0$ & $\mathrm{~d}$ & ${ }^{\mathrm{c}}+53.4 / 0$ \\
\hline poly AH${ }^{+}$-poly & 0.2 & $\mathrm{~d}$ & $\mathrm{~d}$ & $\mathrm{~d}$ & ${ }^{\mathrm{c}}+57.0 / 0$ \\
\hline $\mathrm{AH}^{+}$ & 0.05 & $-2.4 /-18.8$ & -1.0 & -1.1 & 0 \\
\hline poly dA-poly dT & 0.1 & $-2.7 /-24.5$ & $-2.7 /-21.5$ & $-1.8 /-22.1$ & 0 \\
\hline
\end{tabular}

${ }^{a}$ Error in $\Delta T_{m}: \pm 0.5^{\circ} \mathrm{C} ;{ }^{\mathrm{b}} \boldsymbol{r}=$ [compound]/[polynucleotide]; ${ }^{\mathrm{c}}$ Biphasic transitions: the first transition at $T m=30^{\circ} \mathrm{C}$ is attributed to denaturation of poly Apoly $\mathrm{U}$ and the second transition at $\mathrm{Tm}=79^{\circ} \mathrm{C}$ is attributed to denaturation of poly $\mathrm{AH}^{+}$-poly $\mathrm{AH}^{+}$since poly A at $\mathrm{pH}=5$ is mostly protonated and forms 5 ds-polynucleotide; ${ }^{\mathrm{d}}$ precipitation.

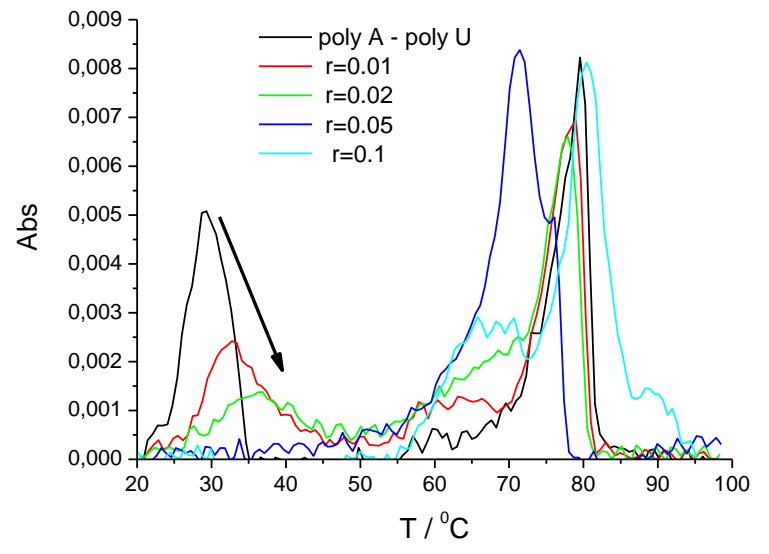

A

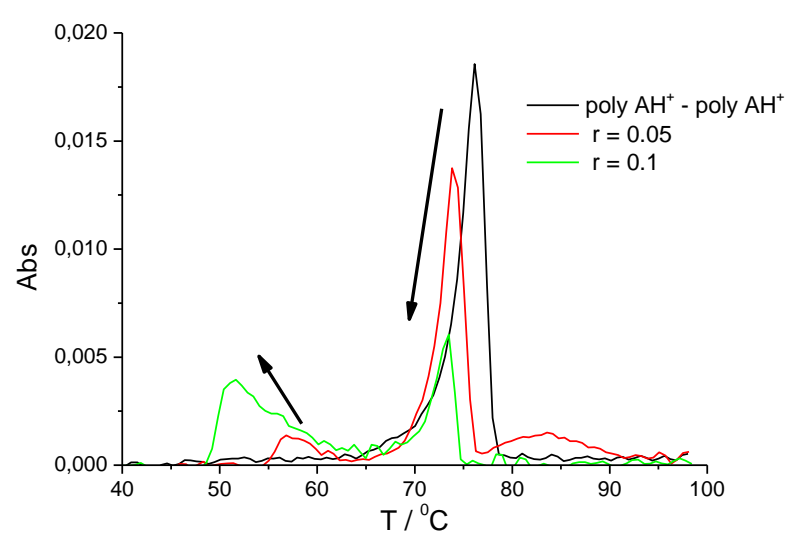

B

Figure 4 Comparison of thermal denaturation experiments ( $1^{\text {st }}$ derivatives of denaturation curves, maxima presenting $T_{m}$ values) of $\mathbf{L}^{4}$ with poly A-poly $\mathrm{U}$ (A) and poly $\mathrm{AH}^{+}$-poly $\mathrm{AH}^{+}(\mathrm{B})$ at various ratios $\mathrm{r}=\left[\mathbf{L}^{4}\right] /[$ polynucleotide $]$.

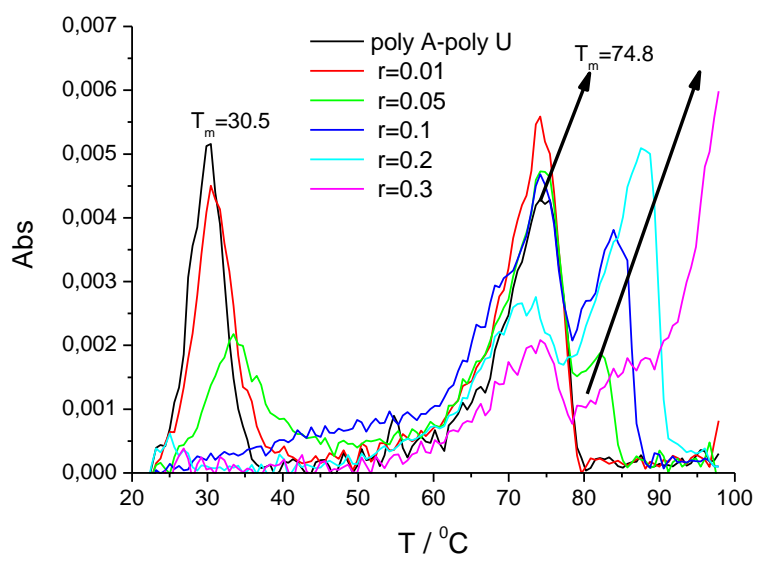

A

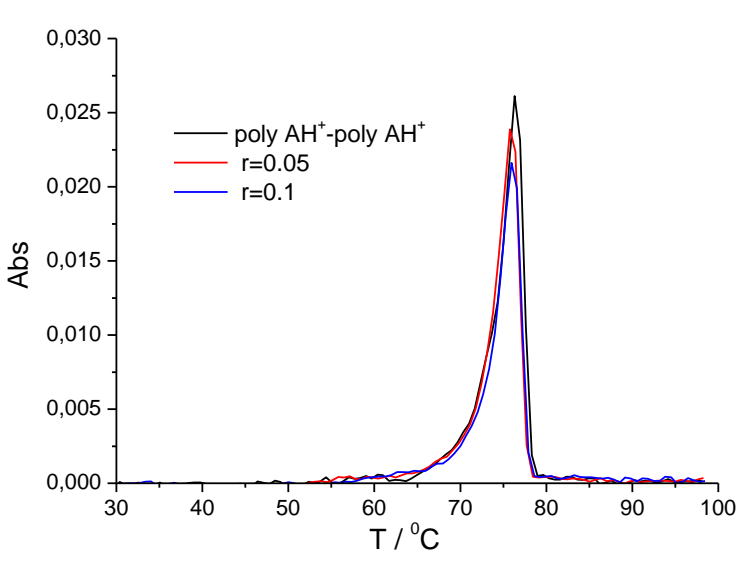

B 
Figure 5 Comparison of thermal denaturation experiments ( $1^{\text {st }}$ derivatives of denaturation curves, maxima presenting $T_{m}$ values) of $\mathbf{L}^{7}$ with poly A-poly $\mathrm{U}$ (A) and poly $\mathrm{AH}^{+}$-poly $\mathrm{AH}^{+}(\mathrm{B})$ at various ratios $\mathrm{r}=\left[\mathbf{L}^{7}\right] /[$ polynucleotide $]$..

For example, all compounds either destabilised or had no effect on poly $\mathrm{AH}^{+}$-poly $\mathrm{AH}^{+}$denaturation, thus transitions ${ }_{5}$ higher than $T_{m}>80{ }^{\circ} \mathrm{C}$ could not be attributed to that polynucleotide but are assigned to denaturation of the compound/poly A-poly U complex. However, $\Delta T_{m}$ values $>30$ ${ }^{\circ} \mathrm{C}$ are not common for poly A-poly $U$, thus a possible formation of very stable triple helical polynucleotide (like the 10 ones observed for DNA analogues) ${ }^{29}$ cannot be neglected.

In order to get insight into the changes of polynucleotide secondary structure induced by small molecule binding, we have chosen Circular Dichroism (CD) spectroscopy. ${ }^{30}$ In addition, achiral small molecules can eventually acquire ${ }_{15}$ induced CD spectrum (ICD) upon binding to polynucleotides, which could give useful information about modes of interaction. ${ }^{30}$ It should be noted that the studied compounds are achiral and therefore do not possess intrinsic $C D$

35

room temperature.

\section{Conclusions}

We have described the protonation and nucleotide coordination properties of new tripodal receptors containing 40 pyridine and imidazole units. The studied compounds bind nucleotide monophosphates in aqueous medium with high affinity, most likely due to the strong electrostatic interactions between positively charged amines and negatively charged phosphates. It is also interesting to point out the formation of 45 stable mononuclear complexes with high stability constant values. Exceptionally strong thermal denaturation effects and efficient displacement of ethidium bromide from DNA/RNA point toward strong interactions of $\mathbf{L}^{4}-\mathbf{L}^{7}$ with double stranded DNA/RNA. In all experiments $\mathbf{L}^{\mathbf{4}}-\mathbf{L}^{\mathbf{6}}$ yielded comparable 50 results, while $\mathbf{L}^{7}$ presents somewhat higher $\Delta T_{m}$ values, most likely due to the higher protonation state that $\mathbf{L}^{7}$ exhibits at $\mathrm{pH}$ 5. Because of the flexible structure, the compounds efficiently adjusted to the polynucleotides (weak CD effects) and absence of any ICD signal suggested that there is no 55 specific binding site within polynucleotide structure. ${ }^{30}$ The aforementioned results suggest that compounds "wrap" around the polynucleotides, forming strong interactions with negatively charged DNA/RNA backbone. However, evidently stronger stabilisation of ds-RNA in comparison with analogue

60 DNA-polynucleotide points toward some type of interaction selective toward RNA. Since ds-DNA and ds-RNA significantly differ in the secondary structure $(\beta$-helix of DNA vs $\alpha$-helix of RNA), ${ }^{28}$ one could speculate that the negatively charged backbone of RNA-double helix gives a better 65 structural match with the positive charges of the compounds than the DNA-double helix. Consequently, the studied compounds exhibit rather rare but therefore even more intriguing ds-RNA over ds-DNA selectivity, which makes interesting further studies in respect to RNA targeting small 70 molecules. ${ }^{31}$ Moreover, due to their high affinity toward DNA and the multiple positive charges, the studied compounds spectrum. Addition of any of the studied compounds didn't 20 induce any significant change in the CD spectra of DNA and RNA (Figures S6 and S7 $\mathrm{ESI}^{\dagger}$ ). Since previous experiments (thermal denaturation, EB displacement) revealed significant affinity of the studied compounds toward DNA/RNA, the only explanation of such minor $\mathrm{CD}$ effects could be that the 25 structural flexibility of the studied compounds allows their easy adjustment to the secondary structure of the polynucleotide, thus not disturbing significantly the helicity of DNA/RNA. In addition, for $\mathbf{L}^{4}-\mathbf{L}^{7} /$ DNA complexes no ICD signal between 220-280 $\mathrm{nm}$ was observed, thus excluding 30 formation of only one dominant binding orientation with respect to the DNA or RNA chiral axis. ${ }^{30}$ Small changes of the poly A-poly $\mathrm{U}$ CD spectrum upon binding of studied compounds excluded formation of any triple helical structure (mentioned in thermal denaturation experiments ${ }^{29}$, at least at

could be considered as analogues of spermidine and similar polyamines with significantly increased DNA polyanion neutralisation and therefore could offer a promising potential 75 to act as artificial histone modulators.

In addition, positive charge of here studied aliphatic amines can be tuned (reversibly) by simple external stimuli like e.g. $\mathrm{pH}$, thus in future studies this can be related to the property of tumor cells in solid tumors, which consistently have lower 80 extracellular $\mathrm{pH}$ levels than normal tissues because of the inefficient clearance of metabolic acids from chronically hypoxic cells. ${ }^{32}$ Tumors of the bladder, kidney and gastrointestinal system in particular are exposed to extremes of $\mathrm{pH}$. However this difference $(0.6-0.8 \mathrm{pH}$ unit) is small in 85 chemical terms and has proved difficult to exploit. Nevertheless, uptake of weakly ionizing drugs by tumours is greatly influenced by the interstitial and intracellular $\mathrm{pH}$, as well as the ionization properties of the drug. Therefore strategies for enhancing and exploiting $\mathrm{pH}$ gradients to drive 90 the uptake of weak acid drugs into tumors are under investigation. ${ }^{33}$

\section{Experimental}

\section{Materials and methods}

95 All chemicals and solvents were obtained from commercial sources and used without further purification. Nucleotide monophosphates were purchased as follows: Adenosine 5'monophosphate disodium salt $\geq 99 \%$ (AMP) from Fluka, Cytidine 5'-monophosphate disodium salt $\geq 99 \%$ (CMP) from 100 Sigma, Guanosine 5'-monophosphate disodium salt hydrate $\geq$ 99\% (GMP) from Sigma, Thymidine 5'-monophosphate disodium salt hydrate $\geq 99 \%$ (TMP) from Sigma and Uridine 5'-monophosphate disodium salt $\geq 98 \%$ (UMP) from Sigma.

Tripodal ligands $\mathbf{L}^{\mathbf{5}}-\mathbf{L}^{\mathbf{7}}$ have been prepared following the 105 general synthetic strategy previously described. ${ }^{15}$ Amine $\mathbf{L}^{\mathbf{1}}$ reacted with the corresponding pyridine or imidazole 
carbaldehydes to give the corresponding pyridine or imidazole functionalized tripodal polyamines. In all cases, a molar ratio carbaldehyde: $\mathbf{L}^{\mathbf{1}}$ 3:1, was used. The overall yield is large enough to obtain all compounds in a gram scale. Elemental 5 microanalysis gave satisfactory values for all ligands. Synthesis of $\mathbf{L}^{\mathbf{5}}-\mathbf{L}^{\mathbf{7}}$ will be reported elsewhere. ${ }^{16}$

\section{Electromotive Force Measurements. Potentiometric Measurements.}

10 The potentiometric titrations were carried out in water at 298.1 $\pm 0.1 \mathrm{~K}$ using $\mathrm{NaCl}$ (for the ligands $\mathbf{L}^{\mathbf{4}}$ and $\mathbf{L}^{7}$ ) or $\mathrm{NaClO}_{4}$ for the ligands $\mathbf{L}^{\mathbf{5}}$ and $\left.\mathbf{L}^{\mathbf{6}}\right) \quad 0.15 \mathrm{~mol} \cdot \mathrm{dm}^{-3}$ as supporting electrolyte. The experimental procedure (burette, potentiometer, cell, stirrer, microcomputer, etc.) has been 15 fully described elsewhere. ${ }^{34}$ The acquisition of the emf data was performed with the computer program PASAT. ${ }^{35}$ The reference electrode was an $\mathrm{Ag} / \mathrm{AgCl}$ electrode in saturated $\mathrm{KCl}$ solution. The glass electrode was calibrated as an hydrogen-ion concentration probe by titration of previously 20 standardized amounts of $\mathrm{HCl}$ with $\mathrm{CO}_{2}$-free $\mathrm{NaOH}$ solutions and determining the equivalent point by the Gran's method, ${ }^{36}$ which gives the standard potential, $\mathrm{E}^{\mathrm{o}}$, and the ionic product obtained were $13.73(1)$ in pure water. ${ }^{37}$ Concentration of the ligand solutions were about $1 \times 10^{-3} \mathrm{~mol} \cdot \mathrm{dm}^{-3}$.

25 The computer program HYPERQUAD was used to calculate the protonation and stability constants. ${ }^{38}$ The $\mathrm{pH}$ range investigated $\left(\mathrm{pH}=-\log \left[\mathrm{H}^{+}\right]\right)$was 2.0-11.0. The different titration curves for each ligand were treated as separated curves without significant variations in the values of the 30 stability constants. Finally, the sets of data were merged together and treated simultaneously to give the final stability constants.

\section{NMR measurements.}

${ }_{35}$ The ${ }^{1} \mathrm{H}$ and ${ }^{13} \mathrm{C}$ NMR spectra were recorded on Bruker Avance DPX $300 \mathrm{MHz}$ spectrometer operating at $299.95 \mathrm{MHz}$ for ${ }^{1} \mathrm{H}$ and at 75.43 for ${ }^{13} \mathrm{C}$. For the ${ }^{13} \mathrm{C}$ NMR spectra, dioxane was used as a reference standard $(\delta=67.4 \mathrm{ppm})$ and for the ${ }^{1} \mathrm{H}$ spectra, the solvent signal. The ${ }^{31} \mathrm{P}$ NMR spectra were 40 recorded on a Bruker Avance DPX $300 \mathrm{MHz}$ operating at 121.495 MHz. Chemical shifts are relative to an external reference of $85 \% \mathrm{H}_{3} \mathrm{PO}_{4}$. Adjustments to the desired $\mathrm{pH}$ were made using drops of $\mathrm{DCl}$ or $\mathrm{NaOD}$ solutions. The $\mathrm{pD}$ was calculated from the measured $\mathrm{pH}$ values using the correlation, ${ }_{45} \mathrm{pH}=\mathrm{pD}-0.4 .^{39}$

\section{Spectroscopic measurements}

The electronic absorption spectra were obtained on Varian Cary 100 Bio spectrometer, CD spectra on JASCO J815 50 spectrophotometer and fluorescence spectra on the Varian Eclipse fluorimeter, all in quartz cuvettes $(1 \mathrm{~cm})$. Spectroscopic studies were performed in aqueous buffer solution $\left(\mathrm{pH}=5\right.$, citrate buffer, $\left.I=0.05 \mathrm{~mol} \cdot \mathrm{dm}^{-3}\right)$. Under the experimental conditions absorbance of $\mathbf{L}^{4}, \mathbf{L}^{\mathbf{5}}, \mathbf{L}^{\mathbf{6}}$ and $\mathbf{L}^{7}$ was 55 proportional to their concentrations. Polynucleotides were purchased as noted: poly A-poly U, poly dA-poly dT, (Sigma) and calf thymus ( $c t$ )-DNA (Aldrich). Polynucleotides were dissolved in sodium cacodylate buffer, $I=0.05 \mathrm{~mol} \cdot \mathrm{dm}^{-3}, \mathrm{pH}$
$=7$. Calf thymus $(c t)$-DNA was additionally sonicated and ${ }_{60}$ filtered through a $0.45 \mu \mathrm{m}$ filter. ${ }^{40,41}$ Polynucleotide concentration was determined spectroscopically ${ }^{41}$ as the concentration of phosphates.

Thermal melting curves for DNA, RNA and their complexes with studied compounds were determined as previously ${ }_{65}$ described $^{41}$ by following the absorption change at $260 \mathrm{~nm}$ as a function of temperature. Absorbance of the ligands was subtracted from every curve, and the absorbance scale was normalized. The $T \mathrm{~m}$ values are the midpoints of the transition curves, determined from the maximum of the first derivative 70 and checked graphically by the tangent method. ${ }^{41} \Delta T \mathrm{~m}$ values were calculated subtracting $T m$ of the free nucleic acid from $T m$ of the complex. Every $\Delta T m$ value here reported was the average of at least two measurements, the error in $\Delta T m$ is \pm $0.5^{\circ} \mathrm{C}$.

75

\section{Acknowledgements}

Financial support from Generalitat Valenciana (GVPRE/2008/017), Ministerio de Ciencia y Tecnología (CTQ2006-15672-CO5-01) and Ministry of Science, ${ }_{80}$ Education and Sport of Croatia (098-0982914-2918) are gratefully acknowledged. M.T.A. wants to thank Ministerio de Educación y Ciencia (Spain) for her Juan de la Cierva contract.

\section{Notes and references}

${ }_{85}{ }^{a}$ Departament de Química Inorgànica, ICMol, Facultat de Química, Universitat de València, Burjassot, Spain.E-mail: enrique.garcia-es@ uv.es; teresa.albelda@uv.es

${ }^{b}$ Departament de Química Orgànica, ICMol, Facultat de Farmàcia, Universitat de València, FGUV, Burjassot, Spain.

$9_{90}{ }^{c}$ Faculty of Pharmacy and Biochemistry, University of Zagreb, Zagreb, Croatia.

${ }^{d}$ Laboratory for Supramolecular and Nucleoside Chemistry. Division of Organic Chemistry and Biochemistry. Rudjer Boskovic Institute, Zagreb, Croatia.E-mail: pianta@irb.hr

95

$\dagger$ Electronic Supplementary Information (ESI) available: [Distribution diagrams for the protonation of the ligands and for the systems L:AMP, protonation constants of nucleotides and NMR spectra]. See DOI: $10.1039 / \mathrm{b} 000000 \mathrm{x} /$

100

1 J. K. Vasir, M. K. Reddy and V. D. Labhasetwar, Curr. Nanosci., 2005, 1, 47; Y. Ito and E. Fukusaki, J. Mol. Cat. B: Enzymatic, 2004, 28, 155.

2 M. Hannon, J. Chem. Soc. Rev., 2007, 36, 280.

3 N. G. Nickols, C. S. Jacobs, M. E. Farkas and P. B. Dervan, Chem. Biol., 2007, 2, 561.

4 J. R. Thomas and P. J. Hergenrother, Chem. Rev., 2008, 108, 1171; J. Gallego and G. Varani, Acc. Chem. Res., 2001, 34, 836; T. Hermann and E. Westhof, Curr. Opin. Biotechnol., 1998, 9, 66.

5 E. H. Blackburn, The RNA World, Eds.: R. F. Gesteland, T. R. Cech and J. F. Atkins, Cold Spring Harbor Laboratory Press, New York, $1999,609$.

6 E. H. Bayne and R. C. Allshire, Trends Genet., 2005, 21, 370.

7 M. Jovanovic and M. O. Hengartner, Oncogene, 2006, 25, 6176; G. L. Sen and H. M. Blau, FASEB J., 2006, 20, 1293.

8 L. Manche, S. R. Green, C. Schmedt and M. B. Mathews, Mol. Cell. Biol., 1992, 12, 5238; C. A. Sledz, M. Holko, M. J. de Veer, R. H. Silverman and B. R. Williams, Nat. Cell. Biol., 2003, 5, 834. 
9 M. J. Fedor and J. R. Williamson, Nat. Rev. Mol. Cell. Biol., 1992, 12, 5238 .

10 T. Hermann, Angew. Chem. Int. Ed., 2000, 39, 1890.

11 H. M. Wallace, A. V. Fraser and A. Hughes, Biochem J., 2003, 376, 1; R. Casero and L. J. Marton, Nat. Rev. Drug Discov., 2007, 6, 373; Y. Wang and R. A. Casero Jr., J. Biochem., 2006, 139, 17.

12 U. Bachrach and Y. M. Heimer, The physiology of polyamines, vol II, CRC Press, 1989.

13 E. W. Gerner and F. L. Meyskens Jr., Nat. Rev. Cancer, 2004, 4, 781.

14 N. Lomadze, H.-J. Schneider, M. T. Albelda, E. García-España and B. Verdejo, Org. Biomol. Chem., 2006, 4, 1755.

15 M. T. Albelda, E. García-España, H. R. Jiménez, J. M. Llinares, C. Soriano, A. Sornosa-Ten and B. Verdejo, Dalton Trans., 2006, 4474.

16 A. Sornosa-Ten, A. -M. Albrecht-Gary and E. García-España, work in preparation.

17 A. Bencini, A. Bianchi, E. García-España, M. Micheloni and J. A. Ramírez, Coord. Chem. Rev., 1999, 188, 97; M. T. Albelda, J. C. Frías and E. García-España, Encyclopedia of Supramolecular Chemistry, 2007, 1:1, 1.

18 C. Frassinetti, L. Alderighi, P. Gans, A. Sabatini, A. Vacca and S. Ghelli, Anal. Bioanal. Chem., 2003, 376, 1041; J. E. Sarnesky, H. L. Surprenant, F. K. Molen and C. N. Reilley, Anal. Chem., 1975, 47, 2116; D. N. Hague and A. D. Moreton, J. Chem. Soc., Perkin Trans. $2,1994,265$.

19 Q. Lu, R. I. Caroll, J. H. Reibenspies, A. E. Martell and A. Clearfield, J. Mol. Struct., 1988, 470, 121; A. Szwajca, B. Leska, G. Schroeder, and M. Szafran, J. Mol. Struct., 2004, 708, 87; M. Koné, B. Illien, C. Laurence, J.-F. Gal and P.-C. Maria, J. Phys. Org. Chem., 2006, 19, 104; B. S. Schafman and P. G. Wenthold, J. Org. Chem., 2007, 72, 1645.

20 A. Sornosa-Ten, N. Humbert, B. Verdejo, J. M. Llinares, M. Elhabiri, J. Jezierska, C. Soriano, H. Kozlowski, A.-M. Albrecht-Gary and E. García-España, Inorg. Chem., 2009, 48, 8985.

21 A. P. De Silva, H. Q. N. Gunaratne, T. Gunnlaugsson, A. J. M. Huxley, C. P. McCoy, J. T. Rademacher and T. E. Rice, Chem. Rev., 1997, 97, 1515; J. L. Sessler, V. Kral, T. V. Shishkanova and P. A. Gale, Proc. Natl. Acad. Sci. USA., 2002, 99, 4848.

22 J.-F. Constant, J. Fahy, J. Lhomme and J. E. Anderson, Tetrahedron Lett., 1987, 28, 1777.

23 M. Shionoya, T. Ikeda, E. Kimura and M. Shiro, J. Am. Chem. Soc., 1994, 116, 3848.

24 S. Aoki and E. Kimura, J. Am. Chem. Soc., 2000, 122, 4542.

25 D. L. Boger, B. E. Fink, S. R. Brunette, W. C. Tse and M. P. Hedrick, J. Am. Chem. Soc., 2001, 123, 5878.

26 I. Piantanida, B. S. Palm, M. Žinić and H.-J. Schneider, J. Chem. Soc., Perkin Trans. 2, 2001, 1808.

27 P. Giri and G. S. Kumar, J. Photochem. Photobiol. A, 2008, 194, 111; G. Malojčić, I. Piantanida, M. Marinić, M. Žinić, M. Marjanović, M. Kralj, K. Pavelić and H.-J. Schneider, Org. Biomol. Chem., 2005, 3, 4373.

28 C. R. Cantor and P. R. Schimmel, Biophysical Chemistry, vol. 3. W. H. Freeman and Co., San Francisco, 1980, 1109.

29 D. P. Arya, L. Xue, and P. Tennant, J. Am. Chem. Soc., 2003, 125, 8070; M. Polak and N. V. Hud, Nucleic Acids Res., 2002, 30, 983.

30 A. Rodger and B. Norden, In Circular Dichroism and Linear Dichroism, Oxford University Press: New York, 1997, Chapter 2.; M. Eriksson, and B. Norden, Methods Enzymol., 2001, 340, 68.

31 J. Gallego and G. Varani, Acc. Chem. Res., 2001, 34, 836.

${ }^{32}$ Tannock IF, Rotin D., Cancer Res. 1989 Aug 15;49(16):4373-84., Wong P, Lee C, Tannock IF, Clin Cancer Res. 2005 May 1;11(9):3553-7, Robert J. Gillies, Ian Robey, and Robert A. Gatenby, J Nucl Med 2008; 49:24S-42S

${ }^{33}$ Natarajan Raghunand, Robert J. Gillies, Drug Resistance Updates (2000) 3, 39-47

34 E. García-España, M. J. Ballester, F. Lloret, J. M. Moratal, J. Faus and A. Bianchi, J. Chem. Soc. Dalton Trans., 1998, 101.

35 M. Fontanelli and M. Micheloni, Proceedings of the I Spanish-Italian Congress on Thermodynamics of Metal Complexes, 1990, Diputación de Castellón, Spain.
36 G. Gran, Analyst, 1952, 77, 881; F. J. Rossotti and H. J. Rossotti, J. Chem. Educ., 1965, 42, 375.

37 A. Avdeef, K. J. Box, J. E. A. Comer, M. Gilges, M. Hadley, C. Hibbert, W. Patterson and K. Y. Tam, J. Pharm. Biomed. Anal., 1999, 20, 631.

38 P. Gans, A. Sabatini and A. Vacca, Talanta, 1996, 43, 1739.

39 P. K. Glasoe and F. A. Long, J. Phys. Chem., 1960, 64, 188; A. K. Covington, M. Paabo, R. A. Robinson and R. G. Bates, Anal. Chem., 1968, 40, 700 .

40 J. B. Chaires, N. Dattagupta and D. M. Crothers, Biochemistry, 1982, 21, 3933.

41 B. S. Palm, I. Piantanida, M. Žinić and H.-J. Schneider, J. Chem. Soc., Perkin Trans. 2, 2000, 385. 